\title{
Using corporate stories to build the corporate brand: an impression management
}

\section{perspective}

Sara Spear, Marketing Department, Portsmouth Business School, University of Portsmouth, Portsmouth, UK

Dr Stuart Roper, Senior Lecturer (Associate Professor) in Marketing, Manchester Business School, The University of Manchester, Manchester, UK

\section{Introduction}

A recent area of academic interest within corporate branding and reputation is the use of storytelling in order to differentiate the corporate brand (Janssen, Dalfsen, Van Hoof and Van Vuuren, 2012). This paper investigates the content of corporate stories, as Janssen et al. (2012) suggest that if corporate stories are useful in reputation building then it is important to know how to use the corporate story most effectively, by firstly understanding the characteristics of corporate stories. Corporate stories are explored from the perspective of impression management (IM) theory, in order to bring insight into how the elements of stories could affect audiences' perceptions of the organisation (Elsbach, Sutton and Principe, 1998), and therefore build the corporate brand, and ultimately the corporate reputation. Although corporate branding research has traditionally focused on multinational corporations, corporate branding in not-for-profit (NFP) organisations is identified as an emerging field in the area (Fetscherin and Usunier, 2012). This paper therefore uses a deductive approach to compare stories from for-profit and NFP organisations. The paper highlights several interesting findings, including that there is a gap between theory and practice in corporate storytelling, as corporate stories often neglect to include elements such as information about the organisation's activities, emotion, benefits for stakeholders 
and links to the corporate strategy. Organisations are therefore missing opportunities to use their corporate story to influence the impressions that audiences form of the organisation, and therefore build the corporate brand.

\section{Corporate storytelling}

Corporate storytelling is suggested to help demonstrate the importance of the corporate brand to internal and external stakeholders, and create a position for the company against competitors, as well as help a firm to bond with its employees (Roper and Fill, 2012). The corporate reputation is defined as a stakeholder's perception of the organisation (Brown, Dacin, Pratt and Whetten, 2006), and Dowling (2006) suggests that if the story causes stakeholders to perceive the organisation as more authentic, distinctive, expert, sincere, powerful, and likeable, then it is likely that this will enhance the overall corporate reputation.

\section{Defining corporate stories}

In order to investigate corporate stories, it is necessary to consider what constitutes a story. There is debate in the literature over the use of the terms 'narrative' and 'story', but stories are suggested to have internal temporality and coherence, whereas narratives do not always have coherent plotlines or characters (Cunliffe, Luhman and Boje, 2004). Stories are suggested to be a type of narrative, such as the definition of organisational stories by Collins (2013) as distinct narrative forms. This paper follows Forster (1963) in considering stories to be a series of logically and chronologically related events. An event is defined by Jameson (2001) as something that happens, rather than something that just exists. This is similar to the definition by Martin, Feldman, Hatch and Sitkin (1983) of an organisational story as one that focuses on a single, unified sequence of events apparently drawn from the 
organisation's history. Gabriel (1991) also suggests that some corporate stories are 'myths', involving heroes and villains, courage, sacrifices, and ordeals. Rowlinson and Procter (1999) propose that events which are mythical are seen as imaginary, indicating that mythical corporate stories could present events which did not actually happen.

\section{Themes and elements of corporate stories}

van Riel and Fombrun (2007) claim that a good corporate story should emphasise the attributes that drive the organisation's reputation, and propose that a core reputation platform is the starting point for developing corporate stories. They identify three reputation platform themes; activities, benefits, and emotion. Multiple authors, including Baker and Boyle (2009), Janssen et al. (2012), Wilkins and Thompson (1991), and Woodside, Sood and Miller (2008), have also suggested elements of corporate stories, based on evidence from conceptual and empirical studies, namely activities, accomplishments, internal and external benefits, emotion, and conflict. There appear to be similarities between the story elements suggested in the literature and the definitions of the reputation platform themes proposed by van Riel and Fombrun (2007), which indicates that different story elements could drive certain aspects of the corporate reputation. The literature also emphasises the importance of including strategic elements, such as the company vision, mission and values, in corporate stories (for example Dowling (2006), Driscoll and McKee (2007), Larsen (2000), Marshall and Adamic (2010), and Marzec (2007)), which indicates that strategy could be another theme of corporate stories. Table 1 summarises how each of the reputation platform themes could be presented by different elements of corporate stories. This is discussed further below. 


\begin{tabular}{|l|l|l|}
\hline $\begin{array}{l}\text { Story } \\
\text { theme: }\end{array}$ & Story element: & Literature source: \\
\hline \multirow{4}{*}{ Activities } & 1. Activities & $\begin{array}{l}\text { Janssen et al. (2012); Larsen (2000); van Riel and } \\
\text { Fombrun (2007); Wilkins and Thompson (1991) }\end{array}$ \\
\cline { 2 - 3 } & 2. Accomplishments & van Riel and Fombrun (2007) \\
\hline \multirow{3}{*}{ Benefits } & 3. Internal benefits & Dowling (2006) \\
\cline { 2 - 3 } & 4. External benefits & Dowling (2006) \\
\hline \multirow{5}{*}{ Emotional } & 5. Emotion & $\begin{array}{l}\text { Baker and Boyle (2009); Barnes (2003); Dowling } \\
\text { (2006) }\end{array}$ \\
\cline { 2 - 3 } & 6. Conflict & McKee (2003); Woodside et al., (2008) \\
\hline \multirow{3}{*}{ Strategy } & 7. Vision & $\begin{array}{l}\text { Baker and Boyle (2009); Dowling (2006); Driscoll and } \\
\text { McKee (2007); Larsen (2000); Marshall and Adamic } \\
\text { (2010); Marzec (2007) }\end{array}$ \\
\cline { 2 - 3 } & 9. Mission & Dowling (2006); Larsen (2000) \\
\cline { 2 - 3 } & 9. Values & $\begin{array}{l}\text { Baker and Boyle (2009); Barnes (2003); Driscoll and } \\
\text { McKee (2007); Marshall and Adamic (2010); van Riel } \\
\text { (2000); van Rekom (1997) }\end{array}$ \\
\hline
\end{tabular}

Table 1: Themes and elements of corporate stories

Activities theme:

The activities theme is proposed to convey the centrality of a key activity or business the organisation is involved in (van Riel and Fombrun, 2007). van Riel and Fombrun (2007) propose that a corporate story should describe the organisation's core activities, abilities, competences, and accomplishments. This agrees with Larsen (2000) who includes competences as a key element of the corporate story, and also empirical evidence in the study by Janssen et al. (2012), who note that core activities are a recognisable characteristic of corporate stories, as they were identified in nearly all of the 45 corporate stories analysed in their study.

Benefits theme:

The benefits theme emphasises the attractive outcomes or benefits stakeholders can expect from the organisation's activities (van Riel and Fombrun, 2007). Benefits are noted as an element of corporate stories, as Dowling (2006) suggests that stakeholders will want both 
common and unique benefits from the company, and the company has to decide whether to tailor the story for each group, or use one story for all. Dowling (2006) proposes that some companies have developed a strong story about their corporate brand that is based mainly on their customer promise, for example Virgin; 'We stand for value for money, quality, innovation, fun and a sense of competitive challenge' ("Virgin", 2012). Employees are a particularly important audience for corporate brand communications (Abratt and Keyn ,2012), and Dowling (2006) proposes that internal and external communication are equally important in creating a good corporate reputation. Therefore benefits aimed at internal and external stakeholders are considered as separate elements of the benefits theme. Emotional theme:

The emotional theme establishes an emotional bond with stakeholders to elicit a personal connection, as a corporate story is proposed to have an emotional appeal (van Riel and Fombrun, 2007), which brings an emotional dimension to an organisation (Roper and Fill, 2012). Dowling (2006) proposes that emotion can attract customers and keep employees motivated, and that a corporate story should create an emotional bond with stakeholders to help foster their trust and support.

Conflict is identified in the literature on storytelling as a key element of stories (such as Adamson, Pine, Van Steenhoven and Kroupa (2006), Booker (2004); Gabriel (2000); Mossberg (2008); Padgett and Allen (1997)), and McKee (2003) emphasises that corporate stories should display the organisation's struggle and show how problems have been overcome. This is included as part of the emotional theme, as the occurrence of blocks, and the steps taken to overcome them, is suggested to increase the audience's emotion and involvement in a story (Woodside et al., 2008). 
Strategy theme:

The corporate story is proposed to articulate the organisation's strategy, by incorporating the corporate mission, vision and values (Larsen, 2000; Marzec, 2007). Dowling (2006) suggests that the story should include elements of the company's mission, and Barnes (2003), Dowling (2006), Driscoll and McKee (2007), Larsen (2000), and Marshall and Adamic (2010) all emphasise the importance of including the corporate values within the story. Roper and Fill (2012) propose that the organisation's values should be explained in the corporate story, to position the corporate brand in the minds of stakeholders. The links to the strategy are important as Suvatjis, de Chernatony and Halikias (2012) state that there needs to be synergy between the corporate strategy and corporate brand.

\section{Means for communicating corporate stories}

Stories can be communicated through press releases, websites, intranets, speeches, and the annual report (Roper and Fill, 2012), as well as management decisions, recruitment and development, investment, approaches to competition and customers, and community stewardship (Marzec, 2007). However, Dowling (2006) proposes that if the story does not resonate inside the company then it will not be portrayed by employees in their encounters with external stakeholders, and if the elements of a corporate story do not fit together then some people may contest the story, it may be ignored, or ridiculed. Corporate stories communicated as part of corporate branding should be based on truth, otherwise the story will fail to gain credibility (Heugens, 2002). However, mythical stories are less likely to be completely true, and therefore some corporate stories may not always be trusted by audiences (Gabriel, 1991). It is generally accepted in the literature that for a corporate story to be effective there must be minimal gaps between the organisation's claims, and its actions (van Riel, 2000; van Riel and Fombrun, 2007). 


\section{Benefits of communicating corporate stories}

Storytelling is proposed to offer benefits in knowledge transfer, by helping people to organise, remember and understand information (Herskovitz and Crystal, 2010; McLellan, 2006; Morgan and Dennehy, 1997; Woodside, 2010), as people are likely to relate the story to experiences already in memory (Woodside, 2010). Stories are also proposed to evoke emotion (Morgan and Dennehy, 1997) and generate an emotional connection with a brand (Herskovitz and Crystal, 2010). The importance of emotion in brand communications has been emphasised by authors such as Leonidou and Leonidou (2009), who propose that emotional appeals attract consumer attention by arousing stronger feelings and interest, and creating a vivid memory of the brand. Dens and De Pelsmacker (2010) suggest that emotional appeals can be used to create or solidify a brand image. Urde (2009) proposes that the corporate brand identity should represent emotional as well as functional and symbolic dimensions, and therefore the corporate brand covenant at the heart of the corporate brand identity could be enhanced by storytelling (Balmer, 2012).

There have been several empirical studies on the use of stories and narratives in marketing communication, such as an experimental quantitative study by Escalas (2004), which found that viewing a narrative storyboard results in a significantly higher self-brand connection compared to viewing the scenes in vignette order. In the NFP context, it is suggested that sharing what an organisation does and how it helps its beneficiaries in a story format helps the organisation differentiate itself (Merchant, Ford, and Sargeant, 2010).

Organisational storytelling is suggested to be an effective form of internal communication, for example Driscoll and McKee (2007) propose that a leader can use stories to engage with their employees, and Marzec (2007) proposes that the corporate story can help employees appreciate their role within the company. The corporate story can communicate values to 
employees (de Chernatony, Cottam, and Segal-Horn, 2006), and can influence and inform employees about the corporate culture (Mossberg, 2008; Smith and Keyton, 2001). These proposed benefits of communicating through stories indicate that corporate storytelling could be effective in corporate branding, by reaching audiences on a rational level (aiding understanding, storage and memory of information), and emotional level (through generating an emotional connection).

In order to gain insight into how corporate stories could build the corporate brand, IM theory is discussed below as a theoretical perspective on corporate storytelling.

\section{Impression management theory}

Elsbach, Sutton and Principe (1998) refer to organisational IM as any action purposefully designed and carried out to influence an audience's perception of an organisation. The origins of IM theory are attributed to Goffman (1959), who presents a dramaturgical perspective of social interactions, which views people as 'actors' engaging in 'performances' before 'audiences' (Gardner and Martinko, 1988). IM theory is a relevant perspective to explore the use of corporate stories in building the corporate brand, as Srivoravilai, Melewar, Liu and Yannopoulou (2011) name it as one of the most influential theories regarding corporate reputation, and Mishina, Block and Mannor (2012) use IM theory to explore the formation of organisational reputations, and propose that companies often use impression management to manage stakeholder perceptions and evaluations. Stanton, Stanton and Pires, (2004) argue that IM provides a rationale for corporate communication, and the study by George (2000) analyses the University of Texas' application of IM techniques to achieve its communication goals. Previous studies have used IM theory to explore forms of corporate communication such as the annual report (such as Merkl-Davies and Brennan (2011), Rahman (2012), and Schleicher (2012)), but there are a lack of studies 
focusing specifically on IM perspectives of corporate stories. The corporate branding literature notes that interactions with brand communications enable stakeholders to form an impression of the organisation (Abratt and Keyn, 2012), and this indicates that IM theory could also therefore bring insight into the use of corporate stories as a form of communication to build the corporate brand.

There are several IM behaviours available to individuals (Carter, 2006), and this can also be extended to organisations. Assertive, defensive, demonstrative and illustrative IM strategies are identified by Bolino, Kacmar, Turnley and Gilstrap (2008), and within the assertive and defensive strategies, specific IM behaviours are also identified. Bolino and Turnley (2003) develop a scale of five assertive IM behaviours, from a taxonomy of IM behaviours presented by Jones and Pittman (1982); 1. ingratiation, 2. self-promotion, 3. exemplification, 4. supplication, 5 . intimidation. These behaviours, alongside behaviours identified by Bolino et al. (2008) and Schlenker and Weigold (1992), are detailed in Table 2.

\begin{tabular}{|l|l|l|}
\hline IM strategy: & IM behaviour: & Definition: \\
\hline \multirow{4}{*}{$\begin{array}{l}\text { Assertive - the organisation } \\
\text { proactively manages } \\
\text { impressions about } \\
\text { themselves to create a } \\
\text { desired image (Tetlock and }\end{array}$} & Ingratiation & $\begin{array}{l}\text { Seeking to be viewed as likeable by } \\
\text { flattering others or doing favours for } \\
\text { them }\end{array}$ \\
\cline { 2 - 3 } \begin{tabular}{l} 
Manstead, 1985) \\
\cline { 2 - 3 }
\end{tabular} & Exemplification & $\begin{array}{l}\text { Communicating the organisation's } \\
\text { abilities and accomplishments, to } \\
\text { appear competent }\end{array}$ \\
\cline { 2 - 3 } & $\begin{array}{l}\text { Showing the organisation as doing } \\
\text { more or better than is necessary, } \\
\text { going beyond the call of duty, to } \\
\text { appear dedicated or superior }\end{array}$ \\
\cline { 2 - 3 } & Supplication & $\begin{array}{l}\text { Showing the organisation's } \\
\text { weaknesses or limitations }\end{array}$ \\
\cline { 2 - 3 } $\begin{array}{l}\text { Defensive - the organisation } \\
\text { reactively manages } \\
\text { impressions about } \\
\text { themselves in order to }\end{array}$ & Intimidation & $\begin{array}{l}\text { Threatening or bullying others } \\
\text { Admitting that an act the } \\
\text { organisation is involved in is wrong } \\
\text { and expressing the organisation's } \\
\text { regret }\end{array}$ \\
\hline
\end{tabular}




\begin{tabular}{|l|l|l|}
$\begin{array}{l}\text { protect their established } \\
\text { image (Tetlock and }\end{array}$ & Excuses & $\begin{array}{l}\text { Attempting to minimise the } \\
\text { organisation's linkage to or } \\
\text { responsibility for a bad act }\end{array}$ \\
\cline { 2 - 3 } & Justifications & $\begin{array}{l}\text { Altering audiences perceptions of an } \\
\text { act the organisation is involved in, } \\
\text { minimising the amount of harm } \\
\text { done, or transforming the act from } \\
\text { bad to good }\end{array}$ \\
\hline $\begin{array}{l}\text { Demonstrative - providing } \\
\text { facts or details about the } \\
\text { specific activities } \\
\text { undertaken by the } \\
\text { organisation (current } \\
\text { activities) (Bolino et al., } \\
\text { 2008) }\end{array}$ & $\begin{array}{l}\text { No behaviours } \\
\text { identified }\end{array}$ & N/a \\
\hline $\begin{array}{l}\text { Illustrative - making broad } \\
\text { generalisations about the } \\
\text { organisation, for example its } \\
\text { wider purpose or aims } \\
\text { (Bolino et al., 2008) }\end{array}$ & $\begin{array}{l}\text { No behaviours } \\
\text { identified }\end{array}$ & N/a \\
\hline
\end{tabular}

Table 2: Definitions of impression management strategies and behaviours (based on Bolino et al. (2008), Bolino and Turnley (2003) and Schlenker and Weigold (1992))

Exploring the IM strategies/behaviours evident in corporate stories can indicate the potential for corporate stories to influence the impressions that audiences form of the corporate brand. Comparing the story elements and IM strategies/behaviours shows that certain story elements could be used as part of IM, illustrated in Table 3 and discussed further below. 


\begin{tabular}{|l|l|l|}
\hline \multirow{4}{*}{ IM strategy: } & \multirow{2}{*}{ IM behaviour: } & $\begin{array}{l}\text { Linked to story } \\
\text { element/s:* }\end{array}$ \\
\hline \multirow{4}{*}{$\begin{array}{l}\text { Assertive } \\
\text { strategy }\end{array}$} & \multirow{3}{*}{ Ingratiation behaviour } & Internal benefits \\
\cline { 2 - 3 } & & External benefits \\
\cline { 2 - 3 } & Self-promotion behaviour & Values \\
\cline { 2 - 3 } & Exemplification behaviour & Accomplishments \\
\cline { 2 - 3 } & Supplication behaviour & External benefits \\
\cline { 2 - 3 } $\begin{array}{l}\text { Defensive } \\
\text { strategy }\end{array}$ & Intimidation behaviour & N/a \\
\cline { 2 - 3 } & Justifications behaviour & Conflict \\
\cline { 2 - 3 } $\begin{array}{l}\text { Demonstrative } \\
\text { strategy }\end{array}$ & Apologies behaviour & Conflict \\
\hline \multirow{2}{*}{$\begin{array}{l}\text { Illustrative } \\
\text { strategy }\end{array}$} & N/a & Activities \\
\hline \multirow{2}{*}{$\begin{array}{l}\text { * Emotion element } \\
\text { used across the strategies/behaviours }\end{array}$} & Vision \\
\cline { 2 - 3 } & N/a & Mission \\
\hline
\end{tabular}

Table 3: Links between impression management strategies/behaviours and story elements

Firstly considering the assertive strategy behaviours, the internal and external benefits elements could be used as part of ingratiation behaviour, as in the study of annual reports by Ogden and Clarke (2005, p. 329), ingratiation was identified as 'sharing benefits with customers', such as rebates and lower bills. This could have an impact on stakeholder perceptions of the corporate brand, as ingratiation behaviour aims to make the organisation appear attractive and likeable (Connolly-Ahern and Broadway, 2007; Young, Gardner and Gilbert, 1994), which could be achieved by communicating what it offers its stakeholders. The values element could also be used as part of ingratiation behaviour, as values are suggested to express the organisation's beliefs and principles (de Chernatony and SegalHorn, 2003; Hall, 1989; Quigley, 1984), and express what the organisation stands for (Verma, 2009-2010), and communicating these could make the organisation more likeable, 
as Edvardsson, Enquist and Hay (2006) propose that brands communicate an organisation's values to create a distinct and favourable image.

The accomplishments element could be used as part of self-promotion behaviour, as this behaviour involves promoting the organisation's achievements. Using this element in stories could have an impact on audiences' impressions of the corporate brand, by showing that it is competent, which is suggested to be related to corporate credibility (Connolly-Ahern and Broadway, 2007), and emphasising the performance and efficiency of the organisation has been proposed as important to differentiate charities (Sargeant et al., 2008). Srivoravilai et al. (2011) also found that self-promotion can help build the corporate reputation. The exemplification behaviour could also use the accomplishments element, by referring to the organisation's achievements in their corporate social responsibility activity, as found in the study by Perks, Farache, Shukla and Berry (2013). The external benefits element could also be used, by showing how the company has provided benefits for the public good (Ogden and Clarke, 2005). Using this behaviour in stories could impact stakeholder perceptions of the corporate brand, by making it appear virtuous and morally worthy (Connolly-Ahern and Broadway, 2007; Young et al., 1994).

The conflict element could be used as part of the supplication behaviour, as this element identifies the problems the company has faced (indicating an area of weakness), but also how these have been overcome (Dowling, 2006; McKee, 2003; Woodside et al., 2008). The conflict element could also be used as part of the defensive strategy (including the justifications, excuses, and apologies behaviours), as this strategy involves the company reacting to a problem that has occurred. This behaviour can impact stakeholder perceptions by helping the brand to gain, maintain or repair its legitimacy, and avoid negative or undesirable qualities being attributed to it (Ogden and Clarke, 2005). 
Using the activities element appears to be a demonstrative strategy, as this strategy involves communicating the activities undertaken by the organisation (Bolino et al., 2008). The demonstrative strategy could impact stakeholders' impressions of the corporate brand, as Merchant et al. (2010) propose that a communicating what a NFP organisation does can differentiate the organisation.

The vision and mission elements could be used as part of an illustrative strategy, as this IM strategy focuses on the organisation's wider purpose and aims, and these can be encapsulated in the organisation's vision and mission (Hirota, Kubo, Miyajima, Hong and Park, 2010; Verma, 2009-2010). The demonstrative and illustrative strategies could influence audiences' perceptions by informing them about key aspects of the corporate brand, in terms of both specific activities and its broader purpose, although these strategies have not been explored so much in the literature as the assertive and defensive strategies. The remaining assertive strategy behaviour, intimidation, is not clearly associated with a particular story element, as stories are not perceived in the literature to be used for threatening audiences. The emotion story element has not been linked here to a particular IM strategy/behaviour, as emotion is proposed as a key element of stories, such as by Gabriel (2000), and different emotions (positive and negative) could potentially be used across the IM strategies; for example pride could be portrayed as part of self-promotion behaviour, whereas fear could be portrayed as part of supplication behaviour.

\section{Literature review conclusion}

The four reputation platform themes could be potential starting points of corporate stories, and could be presented by the elements of corporate stories suggested in the literature. However, the studies which identify these elements are predominantly conceptual (including Barnes (2003), Dowling (2006), Driscoll and McKee (2007); Larsen (2000), Marzec 
(2007), and McKee (2003)), and it is therefore necessary to explore the validity of the themes and elements with empirical research. The IM perspective offers potential insight into how corporate stories could build the corporate brand, by influencing the impressions that stakeholders form of the organisation. The link between themes and elements of corporate stories and IM strategies/behaviours indicates that these elements will influence audiences' perceptions of the corporate brand. The rest of this paper discusses the empirical study undertaken to explore the corporate stories currently presented by organisations.

\section{Method}

The cases in this study were selected from two populations; the FTSE 100 Index, and large charities in England and Wales with an income range of $£ 10,000,001$ and over (a total of 398 charities). The FTSE 100 companies are a suitable population because they include companies from a broad range of industries, which is important as corporate stories may be different according to the industry/industries the company operates in. A census was conducted of the FTSE 100 companies, and 100 large charities were randomly sampled from the population of charities, using a systematic sampling method, so there were an equal number of cases from both sectors.

Data collection and content analysis

Corporate stories were identified from the official website of each organisation in the sample, using the definition of corporate stories as a form of narrative that presents a unified series of logically and chronologically related events about the organisation (based on Forster (1963) and Martin et al. (1983)). Although corporate stories can be presented through many forms of corporate communication, this study focuses on the corporate 
stories presented on organisations' official websites, as it is proposed that strong brand perceptions can be developed online (Simmons, 2007), and the corporate website can be a substantial part of an organisation's external communication (Suvatjis, et al., 2012). From an IM perspective, the corporate website has been proposed as an important IM and image building tool for organisations, because they are a constantly available source of information for an organisation's publics (Connolly-Ahern and Broadway, 2007).

Content analysis was then conducted, in order to identify the elements present in the stories. Content analysis has been used successfully in previous studies in corporate identity and branding, such as Knox and Bickerton (2003), and Opoku, Abratt and Pitt (2006), as well as studies exploring IM in corporate communication, such as Brennan, Guillamon-Saorin and Pierce (2009), Merkl-Davies, Brennan and McLeay (2011), Ogden and Clarke (2005), and Schleicher (2012). The content analysis was undertaken manually and a thematic approach used, as in the study by Brennan et al. (2009). A coding manual was produced by the lead researcher to provide instructions for identifying stories from the organisations' websites and for coding the stories collected for story elements. The coding manual was tested for reliability between the lead researcher and two other coders (discussed below), to firstly ensure consistent identification of corporate stories from organisations' websites, and then to enable content to be coded reliably, and ensure that the content analysis was transparent and objective. The researcher took a deductive approach in the study by determining the themes of the coding manual based on the literature on corporate storytelling. Multiple codes could be assigned to the same data, to allow for multiple meanings within the data. 


\section{Pilot study}

A pilot study of the data collection procedures and content analysis was conducted, to check if the required data could be found on organisations' websites, and in which sections of the websites. The pilot study found that corporate stories can be identified by looking at the 'About Us', or similar, sections of an organisation's website, and also using the website's search engine to search for 'story' and 'history'. Reliability of the coding manual was tested based on agreement between three coders (the primary researcher, one coder who was familiar with the topic, and one coder who was unfamiliar with the topic); the coding manual was used by the two other coders to collect and code data independently from the primary researcher, and then the inter-coder reliability levels were measured. According to Neuendorf (2002), reliability coefficients of .80 or greater are acceptable; this was therefore the minimum reliability level accepted, and the instructions for both the initial identification of corporate stories, and the coding of stories, met this requirement. Any discrepancies in the coding of the pilot study were discussed between the coders and the coding manual revised, in order to improve the reliability of the final study, following the procedure used in the study by Brennan et al. (2009). The reliability of the coding manual was tested again during the final study, which also resulted in inter-coder reliability scores of above .80 , meaning that the coding manual produced an acceptable level of reliability and could be used by other researchers to replicate this study.

\section{Research Findings}

The websites of all the FTSE 100 Index companies and 100 charities were searched for corporate stories. Stories were presented on the websites of around half of both FTSE 100 companies and charities (47\% and 52\%), therefore 99 organisations and their corporate stories were included in the analysis. Some corporate stories were spread across more than 
one page of the organisation's website, and these sections were therefore all included in the pool of data for analysis. The FTSE 100 company stories were on average slightly longer than the charity stories (average word length of 2134 for the FTSE 100 company stories and 1991 words for the charity stories).

Story themes and elements present in corporate stories

There are differences in the elements identified between the two populations, summarised in Table 4.

\begin{tabular}{|c|c|c|c|c|}
\hline $\begin{array}{l}\text { Story } \\
\text { theme: }\end{array}$ & Story element: & $\begin{array}{l}\% \text { of FTSE } \\
100 \\
\text { company } \\
\text { stories } \\
\text { with } \\
\text { element: }\end{array}$ & $\begin{array}{l}\% \text { of } \\
\text { charity } \\
\text { stories } \\
\text { with } \\
\text { element: }\end{array}$ & $\begin{array}{l}\text { Total \% of } \\
\text { stories } \\
\text { with } \\
\text { element: }\end{array}$ \\
\hline \multirow[b]{2}{*}{ Activities } & 1. Activities & $36.20 \%$ & $51.90 \%$ & $44.40 \%$ \\
\hline & $\begin{array}{l}2 . \\
\text { Accomplishments }\end{array}$ & $85.10 \%$ & $75 \%$ & $79.80 \%$ \\
\hline \multirow{2}{*}{ Benefits } & $\begin{array}{l}\text { 3. Internal } \\
\text { benefits }\end{array}$ & $10.60 \%$ & $9.60 \%$ & $10.10 \%$ \\
\hline & $\begin{array}{l}\text { 4. External } \\
\text { benefits }\end{array}$ & $40.40 \%$ & $75 \%$ & $58.60 \%$ \\
\hline \multirow{2}{*}{ Emotional } & 4. Emotion & $23.40 \%$ & $61.50 \%$ & $43.40 \%$ \\
\hline & 5. Conflict & $44.70 \%$ & $51.90 \%$ & $48.50 \%$ \\
\hline \multirow{3}{*}{ Strategy } & 6. Vision & $8.50 \%$ & $1.90 \%$ & $5.10 \%$ \\
\hline & 7. Mission & $4.30 \%$ & $11.50 \%$ & $8.10 \%$ \\
\hline & 8. Values & $21.30 \%$ & $5.80 \%$ & $13.10 \%$ \\
\hline
\end{tabular}

Table 4: Story themes and elements identified in corporate stories

The number of stories with each element varied widely, indicating that organisations place greater importance on the inclusion of some elements in their corporate stories than others. The accomplishments element (part of the activities theme) was identified most frequently (in $85.1 \%$ of FTSE 100 company stories and $75 \%$ of charity stories), indicating that organisations in both sectors focus on promoting their successes in corporate stories. The self-promotion IM behaviour is evident in the use of the accomplishments element, for 
example in the Amnesty International story; 'we have become the biggest and most trusted voluntary organisation in the world', as is the exemplification behaviour (focusing on achievements associated with corporate social responsibility), for example in the BT Group story; 'we are twice winners of the Queen's Award for Enterprise for Sustainable Development'.

The activities element was identified less frequently (in $36.2 \%$ of FTSE 100 company stories, and $51.9 \%$ of charity stories). The demonstrative strategy is evident in the use of the activities element, for example in the RSPCA story; 'we are working with China to develop its first animal welfare law'. This indicates that charities use the demonstrative strategy more in their stories to inform audiences about their activities, perhaps because they have less awareness than the well-known brand names in the FTSE 100 Index.

Activities and accomplishments are internally focused facts, and are predominantly an informational appeal, whereas the literature suggests that emotional appeals are more effective in communicating with stakeholders and building brands (such as Leonidou and Leonidou (2009)), indicating that the activities theme may not be the most effective to use in corporate stories. However the activities theme could be a starting point for stories to build the corporate brand by showing the activities of the organisation, and establishing its competence. Organisations in both sectors could include more information about their activities in their stories, particularly as it is suggested that sharing what the organisation does can differentiate a charity (Merchant et al., 2010), and could therefore also differentiate corporate brands in both the for-profit and NFP sectors.

The emotional story theme comprises the conflict and emotion elements, and both of these elements are identified less frequently than accomplishments. The literature indicates that charities should use an emotional appeal in their communication (Merchant et al., 2010), 
whereas under two thirds of charity stories (61.5\%) included the emotion element. The FTSE 100 companies used emotion even less than the charities, in only $23.4 \%$ of stories, which is again surprising as the literature on storytelling emphasises the importance of emotion in stories (such as Herskovitz and Crystal (2010), and Woodside (2010)). The emotion element is associated with multiple IM strategies/behaviours due to the range of possible emotions being portrayed, for example in the BP story the ingratiation behaviour portrays positive emotion; 'Car owners were ready for service with a smile', and the supplication behaviour portrays negative emotion; 'But things would get worse before getting better. Smallpox and typhus swirled through the nearby countryside. Something close to hysteria gripped the community'.

Similarly, conflict was only used in $51.9 \%$ of charity stories, and therefore many charities are overlooking the potential to include how they have overcome barriers and resistance in their stories. Conflict was again identified less frequently in the FTSE 100 company stories (44.7\%). The conflict element showed evidence of the supplication behaviour, as well as the apologies, excuses and justifications behaviours. Interestingly, companies in controversial industries, such as banking, oil, and tobacco, often used supplication behaviour as part of the conflict element in their corporate stories, including Royal Bank of Scotland (RBS) Group, HSBC, BP, Rio Tinto, Royal Dutch Shell, and British American Tobacco. For example in RBS' story; 'We have recently entered an exceptionally difficult period of our history...some of our major strategic decisions were subsequently shown to be bad mistakes'. The limited use of the conflict element and supplication behaviour however indicates that the FTSE 100 companies in particular are not maximising the effectiveness of their corporate stories, as this behaviour could be used to portray these companies in a vulnerable and sympathetic light, to encourage audiences to form a more favourable impression of the corporate brand. 
The defensive strategy behaviours (excuses, justifications, and apologies) were occasionally used as part of the conflict element, mostly in FTSE 100 company stories. This could indicate either that the for-profit companies are more likely than charities to commit bad acts, for which they need to defend themselves, or that attention from the media and calls for greater transparency have made them more open than the charities in their stories. Imperial Tobacco Group for example uses the excuses behaviour to minimise the organisation's responsibility for what could be perceived as a bad act; 'By the end of 1993 the number of employees had fallen to 2,500. Given the establishment of the Single European Market in 1993, Imperial's actions were not surprising. It had to improve efficiency and reduce production costs to compete with its European counterparts'. Justifications behaviour was identified where the organisation attempted to minimise the amount of harm done by an act, or transform the act from bad to good, for example from Rio Tinto's corporate story; 'A major disaster in which ten employees died in an underground mine in Austria intensifies Rio Tinto's journey to achieve zero harm....Rio Tinto subsequently initiated Group wide safety management systems...Today Rio Tinto has one of the best safety records in the industry'. Apologies behaviour is used in BP's corporate story, where they express regret that 'In the early part of the 20th century, the industry's effects on the natural environment didn't feature on many boardroom agendas. Sadly that may have included Anglo-Persian, the company that later became BP...'.

This indicates that the defensive strategy behaviours can be used in corporate branding to explain and attempt to make amends for bad behaviour. However, these behaviours were mainly used in referring to past events, rather than recent negative events, for example BP's oil spill in the Gulf of Mexico. Corporate failures were also largely ignored, for example M\&S 
do not discuss failures in their international expansion, such as in France in the early 2000s. By not using defensive IM behaviours to react to recent negative events and address corporate failures, organisations are missing the opportunity to use their corporate stories as part of their crisis communication to excuse, justify or apologise for their actions.

There were large differences in the identification of the elements in the benefits theme. External benefits were identified in a relatively high number of charity stories (75\%) but in only $40.4 \%$ of FTSE 100 company stories. The lack of emphasis on external benefits by the FTSE 100 companies is surprising, as for-profit companies should convey to stakeholders what the company will deliver in terms of products, services, and customer experiences (Roper and Fill, 2012), and communicating benefits should also be important for charities, as they often exist for the benefit of a group in need, or society in general (Roper and Fill, 2012), and communicating how beneficiaries are helped can also enable the charity to differentiate itself (Merchant et al., 2010). Benefits for internal stakeholders are infrequently included by either the FTSE 100 companies or charities (in only $10.6 \%$ of the FTSE 100 company stories and $9.6 \%$ of the charity stories), which is concerning, as internal branding is important to ensure that employees deliver on the corporate brand promise (Punjaisri, Wilson and Evanschitzky, 2008). Ingratiation behaviour is evident in the use of internal and external benefits elements, for example the external benefits element in ARM's corporate story; 'ARM's business model...enabled multiple companies to benefit from ARM's innovation', and the internal benefits element in GSK's corporate story; 'GSK to reimburse $100 \%$ of uncapped tuition fees for all undergraduates it recruits in the UK', which aims to enhance the likeability of the companies with their stakeholders by expressing how the company acts in their favour. The exemplification behaviour is also evident in the 
external benefits element, by expressing benefits provided to wider communities beyond the organisation's immediate stakeholders, such as in in G4S' corporate story; 'The work we do helps to ensure the safety and welfare of millions of people'. The lower use of internal and external benefits in stories indicates that organisations are missing the opportunity to promote the benefits they offer in their stories, and to ingratiate themselves with stakeholders.

The strategy theme is neglected in most corporate stories, and vision, mission, and values statements generally appeared separately on the websites. The values element is identified in only $21.3 \%$ of FTSE 100 company stories, and $5.8 \%$ of charity stories. The ingratiation strategy is evident in the values element by promoting characteristics of the organisation that will hopefully appeal to stakeholders and enhance the corporate brand, for example in HSBC's story; 'core values of financial strength and stability'. As values are so crucial in corporate branding, and stories are an effective way of transmitting values (de Chernatony et al., 2006), the lack of this element is a big omission. In the charity context in particular it is thought that values can make the direction of the organisation clear, and can be used to identify potential new staff who hold similar values (Roper and Fill, 2012). Even fewer stories included the vision and mission elements (8.5\% and $4.3 \%$ of FTSE 100 company stories, and $1.9 \%$ and $11.5 \%$ of charity stories). The illustrative strategy is evident in the vision and mission elements, which communicate the company's broader purpose and aims, such as Unilever's vision; 'working to create a better future every day with brands that help people look good, feel good and get more out of life', and St Dunstan's mission; 'to help blind ex-Service men and women lead independent and fulfilling lives'. The limited use of the illustrative strategy is surprising, as the corporate branding literature emphasises the importance of these elements, for example it is proposed that the corporate brand should 
reflect the organisation's vision (Roper and Fill, 2012). By not including these elements, both the FTSE 100 companies and charities are missing the opportunity to use stories to articulate the corporate strategy (Marzec, 2007) and build the corporate brand.

\section{Discussion}

This paper has identified themes and elements of corporate stories, and introduced the use of IM theory to explain the impact of corporate stories on the corporate brand. The main contributions of this study are in identifying a gap between the theory and practice of corporate storytelling, with organisations in both the for-profit and NFP sectors missing opportunities to maximise the effectiveness of their corporate stories. Many organisations neglect activities, benefits, emotion, and strategy in their corporate stories, and focus instead on their accomplishments. Charities appear to be slightly more effective in their storytelling activity through the greater use of benefits and emotion, but there is room for improvement in the stories in both sectors, discussed further below. The study also contributes to the literature by illustrating that IM theory could explain the impact that stories could have on an organisation's stakeholders, and the links proposed between the story elements and IM strategies/behaviours indicate that story elements can affect audiences and build the corporate brand in different ways.

There were several surprising findings in the study, namely the greater emphasis on the accomplishments element (part of the activities theme) in the stories rather than the benefits, emotion, and strategy themes. There are positive aspects of including accomplishments in corporate stories, as accomplishments are part of the self-promotion behaviour, which has been found to help build the corporate reputation from an IM perspective (Srivoravilai et al., 2011). However, the literature indicates that the other 
themes are important in corporate storytelling. For example, a key part of corporate branding is communicating benefits to stakeholders (Schultz and Kitchen, 2004), and there could be greater use of ingratiation behaviour in communicating benefits to stakeholders, to show what the organisation offers different groups and make it more likeable. Corporate stories should increase the use of the vision and mission elements as part of an illustrative IM strategy, in order to articulate the corporate strategy (Marzec, 2007). The activities element, part of the demonstrative strategy, is also suggested to be important to differentiate the corporate brand by communicating what the organisation does (Merchant et al., 2010). Stories should encourage stakeholders to form an emotional connection with the brand (Herskovitz and Crystal, 2010; Woodside, 2010), and both positive and negative emotions can be portrayed across the IM strategies/behaviours in order to enhance audience engagement with the story.

There are differences in the use of elements between the two sectors, and charities are currently more effective in their storytelling activity than the FTSE 100 companies through their greater use of benefits and emotion in their stories. However, many organisations in both sectors neglect these themes, and also the strategy theme, which indicates that many organisations in both the FTSE 100 Index and charity sector are not using stories effectively to build the corporate brand. Most organisations could improve their stories by focusing more on the benefits they offer stakeholders, using emotion to build a connection with stakeholders, and communicating elements of their corporate strategy.

This study considers stories as a form of narrative, using the definition by Forster (1963) that a story is a series of logically and chronologically related events. However it is arguable whether all the corporate stories presented by organisations in this study are stories according to definitions by authors which stress the importance of emotion and 
entertainment in stories. For example Gabriel (2000) proposes that entertainment and emotion distinguish stories from other narratives, and objective factual or descriptive accounts of events must not be treated as stories. According to this, many of the texts identified as corporate stories in this study are not stories as they lack emotional elements and focus more on facts about the organisation and its activities. These corporate stories could arguably be more accurately defined as corporate narratives, which are simply a chronologically and causally linked sequence of events (Adaval and Wyer, 1998; Bruner, 1990; Escalas, 2004; Padgett and Allen, 1997; Shankar, Elliott and Goulding, 2001).

\section{Limitations and further research}

Although the storytelling literature and the IM perspective recommends that corporate stories are based on truth, so that they have credibility with audiences (Gardner and Martinko, 1988; Heugens, 2002), corporate stories present the official version of the truth, which may not agree with perceptions of other stakeholders. The conflict element, and defensive strategy behaviours are sometimes used in the corporate stories to acknowledge corporate misbehaviour, but there are many negative occurrences and failures that are not included in corporate stories. It can therefore be questioned to what extent corporate stories represent the reality of the organisation, and how the official story compares to unofficial stories within the organisation. Corporate mythology may also be more evident in the unofficial stories told within organisations, as it is thought that myths can reveal people's feelings towards their organisations, and reinforce the organisation's values and culture (Gabriel, 1991).

This paper focused on the stories on organisations' official websites, however there are other sources of corporate stories, such as annual reports and corporate advertising, which 
future research should explore to further understand the impact of corporate stories on the corporate brand. There is also a need to consider stakeholder perceptions of the corporate story and its elements, and how this affects their impressions of the corporate brand. Employees in particular play a critical role in delivering the corporate brand (Hawabhay, Abratt and Peters, 2009; Morhart, Herzog and Tomczak, 2009), and the next stage of this research will explore corporate storytelling from the perspective of organisation members, in order to investigate unofficial corporate stories compared to the official version, and how stories affect employee perceptions of the corporate brand.

\section{References}

Abratt, R., and Keyn, N. (2012) Corporate identity, corporate branding and corporate reputations: Reconciliation and integration. European Journal of Marketing, 46(7/8), 10481063.

Adamson, G., Pine, J., Van Steenhoven, T., and Kroupa, J. (2006). How storytelling can drive strategic change. Strategy and Leadership, 34(1), 36-41

Adaval, R., and Wyer Jr, R. S. (1998). The Role of Narratives in Consumer Information Processing. Journal of Consumer Psychology, 7(3), 207.

Baker, B. and Boyle, C. (2009). The timeless power of storytelling. Journal of Sponsorship, 3(1), 79-87.

Balmer, J. M. T. (2012). Corporate Brand Management Imperatives: Custodianship, Credibility, and Calibration. California Management Review, 54(3), 6-33.

Barnes, E. (2003). What's your story? Harvard management communication letter, 6(7), 3-5.

Bolino, M. C., Kacmar, K. M., Turnley, W. H., and Gilstrap, J. B. (2008). A Multi-Level Review of Impression Management Motives and Behaviors. Journal of Management, 34(6), 1080 1109.

Bolino, M. C. and Turnley, W. H. (2003). More Than One Way to Make an Impression: Exploring Profiles of Impression Management. Journal of Management, 29(2), 141-160.

Booker, C. (2004). The Seven Basic Plots. London: Continuum.

Brennan, N. M., Guillamon-Saorin, E., and Pierce, A. (2009). Impression management:

Developing and illustrating a scheme of analysis for narrative disclosures - a methodological 
note. Accounting, Auditing \& Accountability Journal, 22(5), 789-832

Brown, T. J., Dacin, P. A., Pratt, M. G., and Whetten, D. A. (2006). Identity, intended image, construed image, and reputation: An interdisciplinary framework and suggested terminology. Journal of the Academy of Marketing Science, 34(2), 99-106.

Bruner, J. (1990). Acts of Meaning. London: Harvard University Press.

Carter, S. M. (2006). The Interaction of Top Management Group, Stakeholder, and Situational Factors on Certain Corporate Reputation Management Activities. Journal of Management Studies, 43(5), 1145-1176.

Collins, D. (2013). In search of popular management: Sensemaking, sensegiving and storytelling in the excellence project. Culture and Organization, 19(1), 42-61.

Connolly-Ahern, C., and Broadway, S. C.. (2007). The importance of appearing competent: An analysis of corporate impression management strategies on the World Wide Web. Public Relations Review, 33, 343-345.

Cunliffe, A. L., Luhman, J. T., and Boje, D. M. (2004). Narrative Temporality: Implications for Organisational Research. Organisation Studies (01708406), 25(2), 261-286.

de Chernatony, L., Cottam, S., and Segal-Horn, S. (2006). Communicating Services Brands' Values Internally and Externally. Service Industries Journal, 26(8), 819-836.

de Chernatony, L., and Segal-Horn, S. (2003). The criteria for successful services brands. European Journal of Marketing, 37(7/8), 1095-1118.

Dens, N., and De Pelsmacker, P. (2010). How advertising strategy affects brand and USP recall for new brands and extensions. International Journal of Advertising, 2010, 29(2), 165194.

Dowling, G. (2006). Communicating Corporate Reputation through Stories. California Management Review, 49(1), 82-100.

Driscoll, C., and McKee, M. (2007). Restorying a Culture of Ethical and Spiritual Values: A Role for Leader Storytelling. Journal of Business Ethics, 73(2), 205-217.

Edvardsson, B., Enquist, B., and Hay, M. (2006). Values-based service brands: narratives from IKEA. Managing Service Quality, 16(3), 230-246.

Elsbach, K. D., Sutton, R. I., and Principe, K. E. (1998). Averting Expected Challenges Through Anticipatory Impression Management: A Study of Hospital Billing. Organization Science 19(1), 68-86.

Escalas, J. E. (2004). Narrative Processing: Building Consumer Connections to Brands. Journal of Consumer Psychology,14(1/2), 168-180. 
Fetscherin, M., and Usunier, J. (2012). Corporate branding: an interdisciplinary literature review. European Journal of Marketing, 46(5), 733-753.

Forster, E. M. (1963). 'The Story' and 'The Plot'. In M. McQuillan (Ed.), The Narrative Reader (pp. 44-46). London: Routledge.

Gabriel, Y. (1991). On Organisational Stories and Myths: Why it is easier to slay a dragon than kill a myth. International Sociology, 6(4), 427-442.

Gabriel, Y. (2000). Storytelling in Organisations: Facts, Fictions, and Fantasies. Oxford: Oxford University Press.

Gardner, W. L., and Martinko, M. J. (1988). Impression Management in Organizations. Journal of Management, 14(2), 321-338.

George, A. M. (2000). The New Public Relations: Integrating Marketing and Public Relations Strategies for Student Recruitment and Institutional Image Building-A Case Study of the University of Texas at San Antonio. Journal of Nonprofit and Public Sector Marketing, 7(4), 17-31.

Goffman, E. (1959). The Presentation of the Self in Everyday Life. London: The Penguin Press.

Hall, J. (1989). Values, The Key to Business in 1990 and Beyond. Journal of Marketing Management, 5(2), 123-132.

Hawabhay, B., Abratt, R., and Peters, M. (2009). The Role of Corporate Communications in Developing a Corporate Brand Image and Reputation in Mauritius. Corporate Reputation Review, 12(1), 3-20.

Herskovitz, S., and Crystal, M. (2010). The essential brand persona: storytelling and branding. Journal of Business Strategy, 31(3), 21-28.

Heugens, P. (2002). Managing public affairs through storytelling. Journal of Public Affairs, 2(2), 57.

Hirota, S., Kubo, K., Miyajima, H., Hong, P., and Park, Y. W. (2010). Corporate mission, corporate policies and business outcomes: evidence from Japan. Management Decision, 48(7), 1134-1153.

Jameson, D. A. (2001). Narrative Discourse and Management Action. Journal of Business Communication, 38(4), 476-511.

Janssen, S., Van Dalfsen, C. K. A., Van Hoof, J. J., and Van Vuuren. M. (2012). Balancing uniqueness and similarity: A content analysis of textual characteristics in Dutch corporate stories. Public Relations Review, 38(1), 32-39. 
Jones, E. E., and Pittman, T. S. (1982). Toward a general theory of strategic self-presentation. In J. Suls (Ed.), Psychological perspectives on the self (pp. 231-261). Hillsdale, NJ: Lawrence

Knox, S., and Bickerton, D. (2003). The six conventions of corporate branding. European Journal of Marketing, 37(7-8), 998-1016.

Larsen, M. H. (2000). Managing the Corporate Story. In M. Schultz, M. J. Hatch and M. H. Larsen (Ed.), The Expressive Organisation (pp. 196-207). Oxford: Oxford University Press.

Leonidou, L. C., and Leonidou, C. N. (2009). Rational Versus Emotional Appeals in Newspaper Advertising: Copy, Art, and Layout Differences. Journal of Promotion Management, 15(4), 522-546.

Marshall, J., and Adamic, M. (2010). The story is the message: shaping corporate culture. Journal of Business Strategy, 31(2), 18-23.

Martin, J. Feldman, M. S., Hatch, M. J., and Sitkin, S. B. (1983). The Uniqueness Paradox in Organizational Stories. Administrative Science Quarterly, 28(3), 438-453.

Marzec, M. (2007). Telling the corporate story: vision into action. Journal of Business Strategy, 28(1), 26-36.

McKee, R. (2003). Storytelling That Moves People. Harvard Business School Publication Corp, $81,51-55$.

McLellan, H. (2006). Corporate Storytelling Perspectives. Journal for Quality and Participation, 29(1), 17-20.

Merchant, A., Ford, J. B., and Sargeant, A. (2010). Charitable organizations' storytelling influence on donors' emotions and intentions. Journal of Business Research, 63, 754-762.

Merkl-Davies, D. M. and Brennan, N. M. (2011). A conceptual framework of impression management: new insights from psychology, sociology and critical perspectives. Accounting and Business Research, 41(5), 415-437.

Merkl-Davies, D. M., Brennan, N. M., and McLeay, S. J. (2011). Impression management and retrospective sense-making in corporate narratives: A social psychology perspective. Accounting, Auditing \& Accountability Journal, 24(3) 315-344.

Mishina, Y., Block, E. S., and Mannor, M. J. (2012). The path dependence of organizational reputation: How social judgment influences assessments of capability and character. Strategic Management Journal, 33, 459-477.

Morgan, S., and Dennehy, R. F. (1997). The power of organisational storytelling: a management development perspective. Journal of Management Development, 16(7), 494. 
Morhart, F. M., Herzog, W., and Tomczak, T. (2009). Brand-Specific Leadership: Turning Employees into Brand Champions. Journal of Marketing, 73(5), 122-142.

Mossberg, L. (2008). Extraordinary Experiences through Storytelling. Scandinavian Journal of Hospitality and Tourism, 8(3), 195-210.

Neuendorf, K. A. (2002). The Content Analysis Guidebook. London: Sage.

Ogden, S, and Clarke, J. (2005). Customer disclosures, impression management and the construction of legitimacy : Corporate reports in the UK privatized water industry.

Accounting, Auditing \& Accountability Journal, 18(3), 313-345.

Opoku, R., Abratt, R., and Pitt, L. (2006). Communicating brand personality: Are the websites doing the talking for the top South African Business Schools? Journal of Brand Management, 14, 20-39.

Padgett, D., and Allen, D. (1997). Communicating Experiences: A Narrative Approach to Creating Service Brand Image. Journal of Advertising, 26(4), 49-62.

Perks, K. J., Farache, F., Shukla, P., and Berry, A. (2013). Communicating responsibilitypracticing irresponsibility in CSR advertisements. Journal of Business Research, 66, 18811888.

Punjaisri, K., Wilson, A., and Evanschitzky, H. (2008). Exploring the Influences of Internal Branding on Employees' Brand Promise Delivery: Implications for Strengthening CustomerBrand Relationships. Journal of Relationship Marketing, 7(4), 407-424.

Quigley, J. V. (1994). Vision: How leaders develop it, share it, and sustain it. Business Horizons, 37(5), 37-41.

Rahman (2012). Impression Management Motivations, Strategies and Disclosure Credibility of Corporate Narratives. Journal of Management Research, 4(3), 1-13.

Roper, S. and Fill, C. (2012). Corporate Reputation, Brand and Communication. Harlow, Essex: Pearson.

Rowlinson, M., and Procter, S. (1999). Organizational Culture and Business History. Organization Studies (Walter de Gruyter GmbH and Co. KG.), 20(3), 369-396.

Schleicher, T. (2012). When is good news really good news? Accounting and Business Research, 42(5), 547-57.

Schlenker, B. R., and Weigold, M. F. (1992). Interpersonal processes involving impression regulation and management. Annual Review of Psychology, 43(1), 133-168. 
Schultz, D. E., and Kitchen, P. J. (2004). Managing the Changes in Corporate Branding and Communication: Closing and Re-opening the Corporate Umbrella. Corporate Reputation Review, 6(4), 347-366.

Shankar, A., Elliott, R., and Goulding, C. (2001). Understanding Consumption: Contributions from a Narrative Perspective. Journal of Marketing Management, 17(3/4), 429-453.

Simmons, G. J. (2007). "i-branding": developing the internet as a branding tool. Marketing Intelligence and Planning, 25(6), 544-562.

Smith, F. L., and Keyton, J. (2001). Organisational Storytelling: Metaphors for Relational Power and Identity Struggles. Management Communication Quarterly, 15(2), 149.

Srivoravilai, N., Melewar, T. C., Liu, M. J., and Yannopoulou, N. (2011). Value marketing through corporate reputation: An empirical investigation of Thai hospitals. Journal of Marketing Management, 27(3/4), 243-268.

Suvatjis, J., de Chernatony, L., and Halikias, J. (2012). Assessing the six-station corporate identity model: a polymorphic model. Journal of Product and Brand Management, 21(3), 153-166.

Tetlock, P. E., and Manstead, A. S. R. (1985). Impression Management Versus Intrapsychic Explanations in Social Psychology: A Useful Dichotomy. Psychological Review, 92(1), 59-77.

van Rekom, J. (1997). Deriving an operational measure of corporate identity. European Journal of Marketing, 31(5/6), 410.

van Riel, C. B. M. (2000). Corporate Communication Orchestrated by a Sustainable Corporate Story. In M. Schultz, M. J. Hatch and M. H. Larsen (Ed.), The Expressive Organisation (pp. 157-181). Oxford: Oxford University Press.

van Riel, C. B. M., and Fombrun, C. J. (2007). Essentials of Corporate Communication: Implementing practices for effective reputation management. London: Routledge.

Verma, H. V. (2009-2010). Mission Statements - A Study of Intent and Influence. Journal of Services Research, 9(2), 153-172.

Virgin (2012). Retrieved December 1, 2012, from the Virgin website: http://www.virgin.com/about-us

Wilkins, A. L. and Thompson, M. P. (1991). On Getting the Story Crooked (and Straight). Journal of Organizational Change Management, 4(3), 18-26.

Woodside, A. G. (2010). Brand-consumer storytelling theory and research: Introduction to a Psychology and Marketing special issue. Psychology and Marketing, 27(6), 531-540. 
Woodside, A. G., Sood, S., and Miller, K. E. (2008). When consumers and brands talk: Storytelling theory and research in psychology and marketing. Psychology and Marketing, 25(2), 97-145.

Young, J. A., Gardner, W. L., and Gilbert, F. W. (1994) Impression management techniques in marketing channels: A theoretical perspective and research agenda. Journal of Marketing Theory and Practice, 29-38. 